\title{
Exploring the Aesthetic Connotations of Sight-singing and Ear-training
}

\author{
Zhen Zeng ${ }^{1, a}$ \\ ${ }^{1}$ Department of Music, Hankou University, Wuhan city of Hubei Province 430212, China \\ a1775577@qq.com
}

Keywords: sight-singing and ear-training; aesthetic connotation; beauty of tone

Abstract. With the rapid development of the cause of education in China in recent years, sight-singing and ear-training, as introductory and elementary discipline, has received more and more attention. Such kind of attention is not merely reflected in the training of skills. The aesthetic attributes of sight-singing and ear-training also arouse wide concern in academia. For this end, in this paper, we dwell on the aesthetic connotations of sight-singing and ear-training, in the hope of bringing some inspiration to enhance the teaching effect of sight-singing and ear-training, as an introductory discipline.

\section{Introduction}

Sight-singing and ear-training plays a vital role in the creation, performance, appreciation and other artistic practice related to music. But in an actual survey conducted by the author, it was found that such characteristics as boredom and insipidness often affected students' impression of sight-singing and ear-training. Most of the time, this impression would even prejudice students against sight-singing and ear-training. To reverse this stereotyped impression on sight-singing and ear-training is the reason why we dwell on the aesthetic connotations of sight-singing and ear-training in this paper.

\section{The Concept of Sight-singing and Ear-training}

The so-called sight-singing and ear-training is a kind of introductory music teaching through sight-singing and listening practice. Such kind of teaching can train students' music audition ability, music score reading ability, sight-singing ability and intonation and rhythm mastery. Just as the saying goes, "Great oaks grow from little acorns", the training of these abilities is the foundation of music teaching. For sight-singing and ear-training, audition, vision and motion are sense organs that must be engaged in this kind of teaching, so this teaching itself is closer to the foundation of rational knowledge. But from the standpoint of abstract logical thinking, sight-singing and ear-training has extraordinary aesthetic connotations [1].

\section{Analyzing the Aesthetic Connotations of Sight-singing and Ear-training}

With a simple knowledge of the concept sight-singing and ear-training, we also needed to analyze aesthetic connotations of sight-singing and ear-training on a case-by-case basis. Such an analysis mainly revolves around audition and sight-singing.

2.1 Analyzing the aesthetic connotations of audition

When analyzing the aesthetic connotations of audition, the use and imitation-singing, etc. of all kinds of Chinese and foreign musical instruments embodied the aesthetic connotations of sight-singing and ear-training well. Tab. 1 visualizes the aesthetic connotations exhibited in audition in sight-singing and ear-training. From Tab. 1, we can perceive the junior and monotony of the aesthetic feeling of music reflected in sight-singing and ear-training, as well as the significance of such feeling for the training of students' music aesthetics [2]. 
Tab. 1 Aesthetic Connotations Embodied in Sight-singing and Ear-training

\begin{tabular}{lcc}
\hline $\begin{array}{l}\text { Teaching Measures for } \\
\text { Ear-Training }\end{array}$ & Attributes Used & Activities \\
\hline $\begin{array}{l}\text { Combined with musical } \\
\text { instruments }\end{array}$ & $\begin{array}{c}\text { Single-tone; harmonic; } \\
\text { chord; }\end{array}$ & $\begin{array}{l}\text { Various kinds of } \\
\text { Chinese and foreign } \\
\text { musical instruments; } \\
\text { Imitation-singing, } \\
\text { Combined with tones }\end{array}$ \\
$\begin{array}{c}\text { Pitch, duration and } \\
\text { dynamics; }\end{array}$ & $\begin{array}{c}\text { auditory discrimination } \\
\text { and dictation }\end{array}$ \\
\hline
\end{tabular}

Melody and rhythm also played an important role in the aesthetic connotations of audition. Tab. 2 visualizes the aesthetic connotations of melody and rhythm. From this table, we can gain a deeper understanding of the aesthetic connotations of audition.

Tab. 2 Aesthetic Connotations of Melody and Rhythm

\begin{tabular}{lcl}
\hline $\begin{array}{l}\text { Teaching } \\
\text { for } \\
\text { Ear-Training }\end{array}$ & Attributes Used & Activities \\
\hline Melody & $\begin{array}{c}\text { Combined with a pursuit of } \\
\text { the beauty of melody } \\
\text { Combined with the beauty of } \\
\text { Rhythm }\end{array}$ & $\begin{array}{c}\text { A clear goal of skill } \\
\text { training; } \\
\text { rhythm and life vitality }\end{array}$ \\
$\begin{array}{l}\text { that combines rhythm } \\
\text { with movement; }\end{array}$ \\
\hline
\end{tabular}

Analyzing the aesthetic connotations of sight-singing

With a simple knowledge of the aesthetic connotations of audition, we also needed to understand the aesthetic connotations of sight-singing. For sight-singing, both the beauty of tone and tune were manifestations of aesthetic connotations. The author summarized them as musicality and dynamics of singing. Tab. 3 visualizes the composition of these two aspects. From Tab. 3, we can gain a deeper understanding of the aesthetic connotations of sight-singing and ear-training [3].

Tab. 3 Aesthetic Connotations of Musicality and Dynamics of Singing

\begin{tabular}{|c|c|c|}
\hline $\begin{array}{c}\text { Embodiments of } \\
\text { Aesthetic Connotations }\end{array}$ & Basis & Actual Connotations \\
\hline Musicality & Accurate pitch and rhythm; & $\begin{array}{l}\text { Beauty of charm, } \\
\text { "taste" of music; }\end{array}$ \\
\hline Dynamics of Singing & $\begin{array}{l}\text { Melody and } \begin{array}{c}\text { rhythm } \\
\text { composed of high/low, } \\
\text { long/short and strong/weak }\end{array}\end{array}$ & $\begin{array}{l}\text { Beauty of speed and } \\
\text { dynamics }\end{array}$ \\
\hline
\end{tabular}

\section{The Defects of Introductory Teaching of Sight-singing and Ear-training}

With a simple knowledge of the aesthetic connotations of sight-singing and ear-training, we also needed to analyze the defects of introductory teaching of sight-singing and ear-training in depth. This analysis focuses on two aspects: too much emphasis on pure technical training and obsolete teaching methods.

3.1 Too much emphasis on pure technical training

For too much emphasis on pure technical training, the occurrence of this defect was because at present most introductory teaching of sight-singing and ear-training can only be combined with superficial auditory pleasure. As a result, the aesthetic connotations and relevant aesthetic resources of sight-singing and ear-training were ignored. Too much emphasis on pure technical training was evidenced by too much emphasis on logicality and systematicness of textbooks and focus on technical difficulties when writing textbooks. As a result, it was hard for sight-singing and ear-training to coordinate with students in the teaching process. Naturally, it was difficult to convey aesthetic factors to students at the level of emotional experience [4]. 
Obsolete teaching methods

Apart from too much emphasis on pure technical training, obsolete teaching methods were also an embodiment of the defects of introductory teaching of sight-singing and ear-training. Tab. 4 visualizes these obsolete teaching methods. From Tab. 4, we can perceive this defect intuitively.

Tab. 4 Obsolete Teaching Methods

\begin{tabular}{cc}
\hline Obsolete Teaching Methods & Specific Connotations \\
\hline $\begin{array}{l}\text { To teach audition and sight-singing } \\
\text { simply by tapping }\end{array}$ & $\begin{array}{l}\text { They didn’t combine with the dynamic } \\
\text { mental characteristics; } \\
\text { They failed to teach and learn excellent }\end{array}$ \\
$\begin{array}{l}\text { They didn't borrow from "momentum } \\
\text { sight-singing and ear-training methods } \\
\text { teaching method" and "body rhythm } \\
\text { teaching method". }\end{array}$ \\
\hline
\end{tabular}

\section{Conclusion}

In this paper, we carry out a study on the aesthetic connotations of sight-singing and ear-training. The author elaborates on the concept of sight-singing and ear-training, analyzes the aesthetic connotations of sight-singing and ear-training and the defects of introductory teaching of sight-singing and ear-training, etc. From the above, we can gain a deep understanding of the aesthetic connotations of sight-singing and ear-training. It is noteworthy that in recent years, the development of teaching software and the use of acoustic sampling technology related to sight-singing and ear-training brought about by scientific and technological development have been combined with the aesthetic connotations of sight-singing and ear-training intentionally or unintentionally . If we fused these with the teaching reform of sight-singing and ear-training, we would be able to enhance the effectiveness of such kind of teaching substantially.

\section{References}

[1] [1]Toumey C, Cobb M. Nano in Sight: Epistemology, Aesthetics, Comparisons and Public Perceptions of Images of Nanoscale Objects[J]. Leonardo, 2012, 45(5):461-465.

[2]Ilari B, Chenhafteck L, Crawford L. Singing and Cultural Understanding: A Music Education Perspective.[J]. International Journal of Music Education, 2013, 31(2):202-216.

[3]O'Leary J. Oklahoma!, “Lousy Publicity,” and the Politics of Formal Integration in the American Musical Theater[J]. Journal of Musicology, 2014, 31(1):139-182.

[4]Diffey T J. A NOTE ON SOME MEANINGS OF THE TERM 'AESTHETIC’ [J]. The British Journal of Aesthetics, 1995, 35(1). 